\title{
Research on the Integration of STEM Education into the Rural Elementary School Science Curriculum: An Example from Rural Elementary Schools in Western China
}

\author{
Xiuping Qiao, ${ }^{1}$ Xinyi Zhou ${ }^{2}$
}

1. Jiujiang Elementary School, Shuangliu District, Chengdu 610200, Sichuan, China 2. Network and Information Center of Chengdu Normal University, Chengdu 610200, Sichuan, China

\begin{abstract}
Due to the limitation of social economic conditions, the teaching effect of science in rural elementary schools remains unsatisfactory and poorly studied. This research integrates STEM education into rural elementary school science courses to explore whether STEM courses are effective in improving students' knowledge and ability, asking: Are STEM courses better than traditional science courses in improving students' knowledge and abilities? An experimental study of STEM curriculum teaching was conducted in science education at Jiujiang elementary School in Shuangliu County, Chengdu, China. The experimental group receiving STEM classes had increased total score, basic knowledge, and ability expansion compared to the control group receiving traditional classes. This showed that the integration of STEM education into rural elementary school science courses is feasible and effective.
\end{abstract}

Best Evid Chin Edu 2020; 5(1):581-590.

Doi: 10.15354/bece.20.ar034.

Keywords: STEM Education; Chinese Elementary Education; Elementary School Science Curriculum; Rural School; Student Scientific Knowledge and Ability

About the Author: Xiuping Qiao, Principal of Jiujiang Elementary School, Shuangliu District, Chengdu 610200, Sichuan, China. Email: 496569839@qq.com;

Correspondence to: Xinyi Zhou, Professor, Network and Information Center of Chengdu Normal University, Chengdu 610200, Sichuan, China. Email: neemo@126.com. 


\section{Introduction}

$\mathrm{S}$

TEM, short for Science, Technology, Engineering, and Mathematics, emphasizes the intersection and integration of multiple disciplines. Since the introduction of STEM education in the United States in 1986, both developed countries, such as those in Europe and the United States, and developing countries have increasingly paid attention to STEM education. In China, a national strategy exists to vigorously develop STEM education through national policy intervention (Yu \& Hu, 2015). Because STEM education has made outstanding contributions to socioeconomic and technological development in terms of key capabilities and innovative thinking, STEM education research has also become a hot topic that is experiencing rapid development ( $\mathrm{Li}$ et al., 2019). The research includes four categories: STEM conceptualization, educational equity, student academic achievement, and teaching practice. The focus of research is gradually shifting from value-oriented to curriculum practice ( $\mathrm{Du}, 2018$ ).

With the rapid development of STEM education on a global scale, China "has also entered the vigorous development stage of STEM education, and has made significant progress in educational practice, theoretical research and educational policy" (Chinese Academy of Educational Sciences, 2017). In practical research of STEM courses, higher education is the main research object and followed by elementary and middle school education There are also comparative studies on China-American STEM education. However, less research has been done on STEM education courses in areas with rural economic conditions in China. Rural areas in China account for $94.7 \%$ of the country's land area, but this vast land area is economically behind and weaker in basic education than urban areas (Zhang, 2015). In recent years, China has implemented education poverty alleviation policies and education investment in rural areas has been strengthened ( $\mathrm{Yu}, 2006)$. However, due to various factors, such as economics, humanities, family and geography, the teaching of science courses in rural elementary schools is limited, and improvement of students' knowledge and ability in science remains subpar. This paper studies the teaching practice of STEM in the science curriculum of rural elementary schools in China to address the current lack of research on STEM education in rural areas with poor economic conditions and designs a reference STEM curriculum for rural elementary school students in China.

\section{Methods}

\section{Practical Exploration and Research of STEM Courses}

Funding: 2018 Ministry of Education Humanities and Social Sciences Research Planning Project "Research on the Influencing Factors and Effect Mechanisms of STEM Learning Effect of Primary and Secondary School Students" (Project Number: 18YJA880108).

Conflict of Interests: None. 
Jiujiang Elementary School in Shuangliu District, Chengdu is a typical Chinese rural elementary school. In recent years, with the continued advancement of balanced development in education, the educational ecology of this school has greatly improved. However, a questionnaire combined with interviews and observations investigating the current status of the school's science curriculum revealed the following. (i) Due to excessively traditional teaching methods, students' learning initiative and creativity are low. (ii) Students' knowledge is narrow, and their hands-on ability is weak. (iii) Due to inadequate family instruction about the concepts of natural phenomenon, students are easily affected and confused to them. (iv) Although students have a strong interest in science classes, their scientific literacy is low. Here, we focus on the characteristics of elementary school students in rural China, and explore whether, in the science curriculum, STEM teaching has more advantages in training students' knowledge and ability than traditional teaching.

This experimental study addresses the following two questions regarding the integration of STEM education into the elementary science curriculum:

(i) Are STEM courses effective in improving students' knowledge and ability?

(ii) Are STEM courses better than traditional class teaching at improving students' knowledge and ability?

\section{Experimental Design}

The research involved five steps, as outlined below.

(i) From fifth grade students of Jiujiang elementary school in Shuangliu District, 200 students of comparable learning level were divided into a control and experimental groups of 100 each.

(ii) Teaching on "buoyant force" for eight class hours was designed for both traditional and STEM courses.

(iii) Students in the control group experienced the traditional science teaching method, while students in the experimental group experienced the STEM teaching method.

(iv) Questionnaire surveys were given to all students before and after the course study. These tested the students' knowledge and ability. Statistics and analysis on survey responses were done and conclusions drawn.

(v) Through discussion and analysis of survey responses, the content of the courses was modified to improve the teaching design based on the trial teaching, and the final teaching courses formed.

\section{Teaching Design of STEM Unit Courses on "Buoyant force"}

In this study, the "Buoyant force" unit in the fifth-grade science class was selected as the theme for STEM curriculum design. This course has a total of 8 class hours (Table 1).

\section{Compilation of Questionnaire}




\section{Table 1. STEM Course Content.}

\begin{tabular}{|c|c|c|c|c|c|c|}
\hline $\mathrm{CH}$ & Theme & Content \& Process & Sci. & Tech. & Engi. & Math. \\
\hline 1 st & $\begin{array}{l}\text { Preliminary } \\
\text { understand- } \\
\text { ing of buoy- } \\
\text { ancy }\end{array}$ & $\begin{array}{l}\text { 1. Teamwork: Put the foam } \\
\text { block in the water, discuss } \\
\text { why the foam will float on the } \\
\text { water, and complete the } \\
\text { guided learning sheet; } \\
\text { 2. Introduce buoyancy and } \\
\text { visually understand the con- } \\
\text { cept of buoyancy through vid- } \\
\text { eo; } \\
\text { 3. Student cooperation: divide } \\
\text { the foam block to guide stu- } \\
\text { dents to explore the influence } \\
\text { of the same object on the } \\
\text { heave and weight (and com- } \\
\text { plete the record form); } \\
\text { 4. The group conducts commu- } \\
\text { nication summary and report } \\
\text { (the impact of object volume, } \\
\text { etc. on sinking and floating). }\end{array}$ & $\begin{array}{l}\text { The floating } \\
\text { objects made of } \\
\text { the same mate- } \\
\text { rial in the water } \\
\text { are independent } \\
\text { of their weight } \\
\text { and volume. }\end{array}$ & $\begin{array}{l}\text { Cut ob- } \\
\text { jects as } \\
\text { required }\end{array}$ & & $\begin{array}{l}\text { Use the } \\
\text { concept of } \\
\text { fractions } \\
\text { when } \\
\text { cutting }\end{array}$ \\
\hline 2nd & $\begin{array}{l}\text { What fac- } \\
\text { tors are } \\
\text { involved in } \\
\text { floating? }\end{array}$ & $\begin{array}{l}\text { 1. Teachers lead students to } \\
\text { think by guiding students to } \\
\text { observe the floating experi- } \\
\text { ment of putting different }\end{array}$ & $\begin{array}{l}\text { Explore the } \\
\text { factors that } \\
\text { affect floating }\end{array}$ & & & $\begin{array}{l}\text { Number } \\
\text { and sort } \\
\text { as re- } \\
\text { quired }\end{array}$ \\
\hline
\end{tabular}

shapes of play dough into the water;

2. Brainstorming: The teacher allows students to boldly guess the factors affecting the floating, and sort the object's according to their own guesses;

3. In-depth exploration: Predict the floating of different materials in the water and conduct experimental verification in groups to complete the guided learning sheet;

4. The group conducts exchanges and summarizes and reports (factors affecting floating).

\begin{tabular}{|c|c|c|c|c|c|c|}
\hline 3rd & $\begin{array}{l}\text { The floating } \\
\text { of play } \\
\text { dough in the } \\
\text { water }\end{array}$ & $\begin{array}{l}\text { 1. Teachers guide students to } \\
\text { observe and think by demon- } \\
\text { strating the floating of a piece } \\
\text { of play dough in water; } \\
\text { 2. Student's operation: shape } \\
\text { the play dough freely, predict } \\
\text { and verify the their floating; } \\
\text { 3. Brainstorming: Based on the } \\
\text { results of the experiment, } \\
\text { students guess the reasons } \\
\text { that affect floating; } \\
\text { 4. The teacher introduces the } \\
\text { concept of "drained water", } \\
\text { through experiments to verify } \\
\text { the hypothesis and complete } \\
\text { the guided learning sheet. }\end{array}$ & $\begin{array}{l}\text { The volume of } \\
\text { water drained by } \\
\text { an object in the } \\
\text { water is called } \\
\text { the amount of } \\
\text { water dis- } \\
\text { charged }\end{array}$ & $\begin{array}{l}\text { Pinch the } \\
\text { play } \\
\text { dough } \\
\text { into dif- } \\
\text { ferent } \\
\text { shapes }\end{array}$ & $\begin{array}{l}\text { Different } \\
\text { shapes } \\
\text { will affect } \\
\text { the float- } \\
\text { ing of } \\
\text { play } \\
\text { dough }\end{array}$ & $\begin{array}{l}\text { Read the } \\
\text { amount of } \\
\text { water } \\
\text { drained } \\
\text { from the } \\
\text { measuring } \\
\text { cup }\end{array}$ \\
\hline 4th & $\begin{array}{l}\text { Build a } \\
\text { small boat }\end{array}$ & $\begin{array}{l}\text { 1. The teacher introduces the } \\
\text { history of the development of } \\
\text { the ship through a short film, } \\
\text { and let students guess why } \\
\text { the ship can float on the wa- } \\
\text { ter; } \\
\text { 2. Students make hands-on } \\
\text { production: Everyone uses } \\
\text { the same amount of play } \\
\text { dough to make boats in dif- } \\
\text { ferent shapes, and observe } \\
\text { the their floating in the water; }\end{array}$ & $\begin{array}{l}\text { Why can a boat } \\
\text { float on the } \\
\text { water? }\end{array}$ & $\begin{array}{l}\text { Make } \\
\text { different } \\
\text { shapes of } \\
\text { boating } \\
\text { by play } \\
\text { dough }\end{array}$ & $\begin{array}{l}\text { How to } \\
\text { make a } \\
\text { floating } \\
\text { boat? } \\
\text { How to } \\
\text { make the } \\
\text { boat carry } \\
\text { more } \\
\text { weight? }\end{array}$ & $\begin{array}{l}\text { Measure } \\
\text { and rec- } \\
\text { ord the } \\
\text { maximum } \\
\text { weight } \\
\text { that car- } \\
\text { ried ob- } \\
\text { jects }\end{array}$ \\
\hline
\end{tabular}




\begin{tabular}{|c|c|c|c|c|c|c|}
\hline & & $\begin{array}{l}\text { 3. The group's exploration and } \\
\text { research: Thinking about how } \\
\text { to make improvements to } \\
\text { make the boat carry more } \\
\text { weight; } \\
\text { 4. Students improve the boat } \\
\text { and conduct a boat show. }\end{array}$ & & & & \\
\hline 5th & $\begin{array}{l}\text { Buoyant } \\
\text { force }\end{array}$ & $\begin{array}{l}\text { 1. Experiment introduction: Let } \\
\text { students experience the con- } \\
\text { cept of buoyancy by them- } \\
\text { selves; } \\
\text { 2. Discussion by the group: } \\
\text { Whether the volume of the } \\
\text { object in the water affects the } \\
\text { buoyancy, make an explora- } \\
\text { tion research table; } \\
\text { 3. Cooperative learning: learn to } \\
\text { use dynamometer to measure } \\
\text { buoyancy force correctly and } \\
\text { verify the record form; } \\
\text { 4. Summarize the factors that } \\
\text { affect the buoyant force. }\end{array}$ & $\begin{array}{l}\text { Understand the } \\
\text { concept of } \\
\text { buoyant force }\end{array}$ & $\begin{array}{l}\text { Use } \\
\text { spring } \\
\text { dyna- } \\
\text { mometer } \\
\text { to test } \\
\text { buoyant } \\
\text { force }\end{array}$ & $\begin{array}{l}\text { The } \\
\text { Principle } \\
\text { of testing } \\
\text { buoyant } \\
\text { force by } \\
\text { spring } \\
\text { dyna- } \\
\text { mometer }\end{array}$ & $\begin{array}{l}\text { Reading } \\
\text { of spring } \\
\text { dyna- } \\
\text { mometer }\end{array}$ \\
\hline 6th & $\begin{array}{l}\text { Will sink } \\
\text { objects be } \\
\text { affected by } \\
\text { the buoyant } \\
\text { force of } \\
\text { water? }\end{array}$ & $\begin{array}{l}\text { 1. Teachers guide students on } \\
\text { the method of learning exper- } \\
\text { iment verification; } \\
\text { 2. Teamwork: Complete the } \\
\text { experiment and fill in the rec- } \\
\text { ord form; } \\
\text { 3. In-depth exploration and } \\
\text { research: The amount of } \\
\text { buoyant force experienced by } \\
\text { different stones; } \\
\text { 4. Analyze and summarize the } \\
\text { stress on the stones and } \\
\text { foam by drawing: whether the } \\
\text { sinking object is affected by } \\
\text { buoyant force. }\end{array}$ & $\begin{array}{l}\text { Learn how to } \\
\text { verify the exper- } \\
\text { iment }\end{array}$ & & $\begin{array}{l}\text { Control } \\
\text { the vol- } \\
\text { ume of } \\
\text { objects } \\
\text { immersed } \\
\text { in the } \\
\text { water }\end{array}$ & $\begin{array}{l}\text { Calculate } \\
\text { the mag- } \\
\text { nitude of } \\
\text { buoyant } \\
\text { force by } \\
\text { reading } \\
\text { the value } \\
\text { of the } \\
\text { dyna- } \\
\text { mometer }\end{array}$ \\
\hline 7th & $\begin{array}{l}\text { The floating } \\
\text { of potatoes } \\
\text { in the liquid }\end{array}$ & $\begin{array}{l}\text { 1. Teachers demonstrate the } \\
\text { floating of potatoes in differ- } \\
\text { ent liquids through experi- } \\
\text { ments, and introduce the ef- } \\
\text { fects of different liquids on the } \\
\text { floating of objects; } \\
\text { 2. Guess and verify "what is the } \\
\text { liquid in the experiment"; } \\
\text { 3. Teamwork: Set up a control } \\
\text { group to verify the effect of } \\
\text { different liquids on the floating } \\
\text { of objects; } \\
\text { 4. Analyze the rules and draw } \\
\text { conclusions. }\end{array}$ & $\begin{array}{l}\text { Different effects } \\
\text { of different } \\
\text { liquids on the } \\
\text { buoyant force of } \\
\text { objects }\end{array}$ & $\begin{array}{l}\text { Evapo- } \\
\text { rate the } \\
\text { liquid with } \\
\text { an alco- } \\
\text { hol lamp } \\
\text { and ob- } \\
\text { serve }\end{array}$ & & $\begin{array}{l}\text { Measure } \\
\text { the } \\
\text { amount of } \\
\text { water and } \\
\text { dissolve it } \\
\text { with dif- } \\
\text { ferent } \\
\text { amounts } \\
\text { of table } \\
\text { salt }\end{array}$ \\
\hline 8th & $\begin{array}{l}\text { Explore the } \\
\text { causes of } \\
\text { sinking and } \\
\text { floating of } \\
\text { potato }\end{array}$ & $\begin{array}{l}\text { 1. Under the guidance of teach- } \\
\text { ers, students make guesses } \\
\text { about the reasons that affect } \\
\text { the floating of potatoes, de- } \\
\text { sign and make exploration } \\
\text { and research records; } \\
\text { 2. Teamwork: Verify the reason, } \\
\text { complete exploration and re- } \\
\text { search record form; } \\
\text { 3. Analyze the rules and draw } \\
\text { conclusions. }\end{array}$ & $\begin{array}{l}\text { The same object } \\
\text { will experience } \\
\text { different buoyant } \\
\text { force in different } \\
\text { liquids }\end{array}$ & $\begin{array}{l}\text { Use the } \\
\text { balance } \\
\text { correctly } \\
\text { to weigh } \\
\text { the } \\
\text { weight }\end{array}$ & $\begin{array}{l}\text { The } \\
\text { principle } \\
\text { of bal- } \\
\text { ance to } \\
\text { scale } \\
\text { weight }\end{array}$ & $\begin{array}{l}\text { Reading } \\
\text { the value } \\
\text { of the } \\
\text { weight of } \\
\text { the bal- } \\
\text { ance } \\
\text { scale }\end{array}$ \\
\hline
\end{tabular}


The questionnaire used in this experiment includes two parts: basic knowledge (questions 1-10) and ability expansion (questions 11-14). Questions 1-10 are 4 points each, questions 11-12 are 10 points each, and questions 13-14 are 20 points each for a total of 100 points. An example basic knowledge question is: (multiple choices) When the object buoyant force (_) gravity in the water, it sinks. A) Less than; B) Greater than; C) Equal. An example capacity expansion question is: What would our life be like if we lost the buoyant force of water? Try to write a reasonable scenario, the more reasonable the better. Scenario One: __; Scenario Two: __; Scenario Three: _ ; Scenario Four: _. The content of the questionnaire was discussed with teachers several times, and the questionnaire gradually refined.

Cronbach's $\alpha$ coefficient was used to test the reliability of the questionnaire. The basic knowledge and ability expansion of the entire questionnaire had a Cronbach's $\alpha>0.8$, indicating that the questionnaire has high reliability. After analysis by teachers in science, the questions designed by this questionnaire were found to meet the purpose and requirements of the measurement. The basic knowledge questions and ability expansion of the questionnaire are significantly correlated with the content of each question, indicating that the questionnaire is highly effective.

\section{Participants and Steps}

In Jiujiang Elementary School, Shuangliu District, Chengdu, 200 fifth-grade students were selected, including 108 boys (the control: 57, the experimental: 51) and 92 girls (the control: 43, the experimental: 49). To reduce non-experimental variance in the experiment, the knowledge background and learning ability of the teachers and students participating were made roughly the same for the control and experimental groups.

(i) Before the experiment, students in the control and experimental groups completed a questionnaire survey to collect pre-treatment data.

(ii) The students in the experimental group studied STEM courses, while students in the control group studied traditional courses.

(iii) After the experiment, students in the control group and the experimental groups again completed the questionnaire survey to collect post-treatment data.

\section{Statistical Analysis}

All data processing and analysis were done using SPSS v20.0. Assuming that both preand post-experiment questionnaire data of the control group meets the normal distribution, we continued to use the independent sample t-test to compare the control group before and after learning, including testing on the student's total score, basic knowledge, and ability expansion.

\section{Results}

\section{Pre-experiment Data Analysis}


Before the experiment, there are no significant differences in knowledge (effect = 0.037 ), ability expansion (effect size $=-0.065$ ) or total score (effect size $=0.063, \mathrm{P}>$ 0.05 ) between the experimental group and the control group (Table 2).

\section{Comparison between Pre- and Post-experiment Data of the Control Group}

Students in the control group differed significantly in the total score, basic knowledge and ability expansion before and after learning $(P<0.01$; Table 3$)$. The average score of the control group after learning was better than before learning. The effect size was moderate in both pre- and post-experiment tests. This shows that traditional courses can improve students' knowledge level and ability.

\section{Comparison between Pre- and Post-experiment Data of the Ex- perimental Group}

Students in the experimental group differed significantly in total score, basic knowledge and ability expansion before and after learning $(P<0.01$; Table 4$)$. The average score of the experimental group after learning was greater than before learning and the effect size was large in both pre- and post-experiment. This shows that STEM courses can improve students' knowledge level and ability.

\section{Post-experiment Data Analysis}

An independent sample t-test compared the experimental and control groups after learning, including testing on the student's total score, basic knowledge, and ability expansion (Table 5).

After separate learning, students in the two groups differed significantly in total score, basic knowledge and ability expansion $(P<0.01$; Table 5). Overall performance ability expansion had a moderate effect size, and the basic knowledge effect size was large. Thus, the STEM teaching course has advantages over the traditional course when integrated into the science curriculum.

\section{Discussion}

The experimental data reveals that the teaching practice of STEM used in this study was effective in improving the science curriculum knowledge and ability of elementary school students in rural China and had advantages over the traditional science curriculum. The core features of STEM are that it is interdisciplinary, interesting, experiential, situational, collaborative, artistic, empirical, and technologically enhanced. The STEM education curriculum is designed to engage students in learning based on activities, projects, and problem solving that provide a hands-on classroom experience (Wang, 2016). In response to the characteristics of rural elementary school students in China, the teaching design of the STEM science curriculum is as follows. (i) Multidisciplinary 


\section{Table 2: Independent Sample $t$ Test of the Pre-Experiment Data.}

\begin{tabular}{llllll}
\hline & Control Group & Experimental Group & $\boldsymbol{t}$ & $\boldsymbol{P}$ & Cohen's d \\
\hline Overall Score & $46.67 \pm 22.01$ & $48.03 \pm 20.91$ & -0.448 & 0.449 & -0.063 \\
\hline Basic Knowledge & $17.79 \pm 7.52$ & $18.06 \pm 7.03$ & -0.262 & 0.220 & -0.037 \\
\hline Ability Development & $28.90 \pm 17.36$ & $29.96 \pm 15.42$ & -0.457 & 0.087 & -0.065 \\
\hline
\end{tabular}

Note: Data are presented as mean \pm SD, $p<0.05$ means statistically significant.

\begin{tabular}{|c|c|c|c|c|c|}
\hline & Pre-experiment & Post-experiment & $t$ & $\boldsymbol{P}$ & Cohen's d \\
\hline Overall Score & $46.67 \pm 22.01$ & $61.26 \pm 28.09$ & -4.088 & $.000^{* *}$ & -0.578 \\
\hline Basic Knowledge & $17.79 \pm 7.52$ & $23.14 \pm 8.27$ & -4.787 & $.000^{\star *}$ & -0.037 \\
\hline Ability Development & $28.90 \pm 17.36$ & $38.12 \pm 21.98$ & -3.292 & $.000^{* *}$ & -0.466 \\
\hline
\end{tabular}

\section{Table 4: Level Analysis of the Experimental Group Before and} After Learning.

\begin{tabular}{llllll}
\hline & Pre-experiment & Post-experiment & $\boldsymbol{t}$ & $\boldsymbol{P}$ & Cohen's d \\
\hline Overall Score & $48.03 \pm 20.91$ & $71.19 \pm 19.14$ & -8.170 & $.000^{* *}$ & -1.155 \\
\hline Basic Knowledge & $18.06 \pm 7.03$ & $29.96 \pm 5.83$ & -12.438 & $.000^{* *}$ & -1.759 \\
\hline Ability Development & $29.96 \pm 15.42$ & $45.75 \pm 14.58$ & -7.441 & $.000^{* *}$ & -1.052 \\
\hline
\end{tabular}

Note: Data are presented as mean $\pm \mathrm{SD},{ }^{* *} \mathrm{p}<0.01$

\begin{tabular}{llllll}
\hline \multicolumn{7}{l}{ Table 5. Independent Sample $\boldsymbol{t}$ Test of the Post-Experiment Data. } \\
\hline & Control Group & Experimental Group & $\boldsymbol{t}$ & $\boldsymbol{P}$ & Cohen's $\boldsymbol{d}$ \\
\hline Overall Score & $61.26 \pm 28.09$ & $71.19 \pm 19.14$ & -2.921 & $.000^{* *}$ & -0.413 \\
\hline Basic Knowledge & $23.14 \pm 8.49$ & $29.96 \pm 5.83$ & -6.622 & $.000^{* *}$ & -0.937 \\
\hline Ability Development & $38.12 \pm 21.98$ & $45.75 \pm 14.58$ & -2.893 & $.000^{* *}$ & -0.409 \\
\hline
\end{tabular}

Note: Data are presented as mean $\pm S D,{ }^{* *} p<0.01$. 
knowledge should be integrated into real situations that are interesting and closely related to life. Students use brains, hands, and cooperation to improve class participation, develop innovative thinking, and improve problem-solving skills (Sun, 2018). (ii) By providing rich perceptual knowledge, students are stimulated to create "confusion," find new explanations, form new concepts, and this promotes students to change from original concepts to scientific concepts (Lin, 2014). (iii) Through the experience of STEM science courses, students' internal motivation is stimulated, scientific knowledge is accurately understood, advanced thinking is developed, and their ability to solve problems is improved (Chen, 2019).

STEM education has become a hot topic of common concern in current international education research and reform, providing innovative ideas for the new round of basic education science curriculum reform in China. The elementary school stage is a critical period for children's knowledge and ability expansion. At this stage, students have not yet fully formed their own ways of thinking and problem-solving, and thus this is the best period to cultivate innovative ability (Long \& Zhao, 2015). An increasing number of empirical studies suggest that children's scientific interests are formed before the age of 14 years (Tai et al., 2006). Rural areas in China can combine their own characteristics with the existing practices of related cities in China and advanced foreign experience (Zhu \& Lei, 2018) to actively promote the exploration of STEM education, carry out STEM education actions, and improve the ecology of STEM education construction. This requires gathering all social forces, including schools, libraries, science centers and museums, extracurricular tutoring institutions, enterprises, higher education institutions, communities, and families, etc. (Chen et al., 2019).

How to Cite: Qiao, X., Zhou, X. (2020) Research on the integration of STEM education into the rural elementary school science curriculum: An example from rural elementary schools in Western China. Best Evid Chin Edu, 5(1):581-590. Doi: 10.15354/bece.20.ar034.

\section{References}

Capraro, R.M., Capraro, M.M., \& Morgan, J.R. Translated by Wang X. (2016) Project-based STEM learning: An integrative science, technology, engineering and mathematics learning methods. Shanghai Sci Tech Edu Press, (1):III-6.

Chen, L. (2019) Activity-based STEM classroom management strategy for elementary 
schools. Shanghai Edu Eval Res, (02):45-48 +70 .

Chen, P., Tian, Y., \& Liu W. (2019) Polaris project: Global innovation talent cultivation with STEM education as the core - Analysis of "Developing a successful Route: American STEM education strategy" (2019-2023). Dist Edu J, 37(2): 3-14.

Chinese Academy of Educational Sciences. (2017) China STEM Education Self-Book (Essential Edition). Beijing: Chinese Academy of Educational Sciences.

Du, W. (2018) Analysis of hot topics and characteristics of foreign STEM education research. Audiovis Edu Res, 39 (11):120-128.

Fu, Q., Liu, P. (2016) From verification to creation - Study on the application model of STEM education in elementary and secondary schools. Chin Audiovis Edu, (04):71-78 +105 .

Li, Y., Wang, K., \& Xiao, Y. (2019) The current status and development trend of STEM education research: A review of papers published in journals from 2000 to 2018 . J Math Edu, 28 (03):45-52.
Lin, Z. (2014) Analysis and application of prescience concepts. Edu, (12):50-50.

Long, M., Zhao, Z. (2015) American national competitiveness: Contribution of STEM education. Modern Univ Edu, (02): 41-49 + 112.

Sun, Y. (2018) Integration of STEM Education in elementary school science curriculum. Edu Sci Forum, 446 (32):45-48.

Tai, R.H., Liu, C.Q., Maltese, A. V., \& Fan, X. (2006) Planning, early for careers in science. Science, 312 (5777): 1143-1144.

Yu, S., Hu, X. (2015) STEM education concept and interdisciplinary integration model. Open Edu Res, 21 (04):13-22.

Yu, Y. (2006) National investment and educational development in China. Theor Guide, (9):70-72.

Zhang, M. (2015) Analysis of the characteristics and reform suggestions of basic education in China. Higher Edu Res Southwest Univ Sci Tech, (3):27-29.

Zhu, Z., Lei, Y. (2018) National policy analysis and practice model of STEM education. Audiovis Edu Res, (1):75-85.

Received: 16 February 2020

Revised: 02 April 2020

Accepted: 06 April 2020 